VARIA

\title{
Plato or Platonism. A topic in descending dialectic
}

Platão ou Platonismo. Um tópico em dialética descendente*

**Eduardo Luft

\begin{abstract}
Dialectical ontology can be reconstructed following two complementary path $\mathbf{s}^{1}$. The ascending path (anabasis) begins with the influence of Plato's ontology through Nicholas of Cusa on Bertalanffy ${ }^{2}$, the founder of systems theory. Converging with Darwinism, this theoretical approach will give rise to the more refined version of the complex adaptive systems theory, and will ultimately spread out through the different sciences, converting from a regional ontology (ontology of biology) into a major part of a new general ontology (theory of being as being, that obviously should not be understood here as a merely formal ontology ${ }^{3}$ ). The descending path (katabasis), the eminently philosophical one, also has two branches which ultimately converge: on the one hand it leads from Plato's theory of ideas to German idealism and seeks to establish itself by immanent critique of Hegel's system (a topic that has for a long time been my main occupation $^{4}$ ); the second branch of this descending dialectic is the subject of this essay, namely, the investigation of the decisive role of self-critical development of Plato's philosophy in the project of a deflationary relational ontology or, simply, a network ontology.
\end{abstract}

Keywords: Plato; Platonism; Hegel; dialectical ontology; network ontology.

Resumo: A ontologia dialética pode ser reconstruída percorrendo dois caminhos complementares. A via ascendente (anabasis) parte da influência da ontologia de Platão, mediada por Nicolau de Cusa, sobre Bertalanffy, o fundador da teoria de sistemas. Esta abordagem teórica, uma vez convergindo com o darwinismo, dará nascimento

\footnotetext{
*A Portuguese version of this paper was presented in Luft, 2014b.

**Professor Doutor, PPGF/PUCRS. <eduardo.luft@pucrs.br>.

1 Luft, 2014a, p. 949ss.

2 Cirne-Lima, "Causalidade e auto-organização", in Luft \& Cirne-Lima, 2012, p. 153ss.

For general ontology as formal ontology in Husserl, see Dostal, 1993, p. 143.

4 Luft, 2001.
} 
à teoria dos sistemas adaptativos complexos e logo se espalhará pelas diversas ciências, transmudando-se de uma ontologia regional (ontologia da biologia) em parte relevante de uma nova ontologia geral (uma teoria do ser enquanto ser que, obviamente, não deve ser confundida aqui com uma ontologia meramente formal). O caminho descendente (katabasis), a via eminentemente filosófica, também parte de dois ramos distintos que, ao final, convergem: por um lado, esta via conduz da teoria das ideias de Platão ao idealismo alemão e à crítica imanente ao sistema de Hegel (tópico que tem sido, por um longo tempo, minha ocupação principal de pesquisa); por outro lado, e este será nosso tópico principal no presente ensaio, ela investiga o impacto decisivo do desenvolvimento autocrítico da filosofia de Platão sobre o projeto de uma ontologia relacional deflacionária ou, simplesmente, uma ontologia de redes.

Palavras-chave: Platão; platonismo; Hegel; ontologia dialética; ontologia de redes.

\section{From Hegel to Plato}

Tn order to highlight the importance of renewing the dialogue with Plato, $\perp$ I wish to begin by analyzing the achievements and limits of the proposal to update the dialectical ontology by Cirne-Lima. This will show us why only on returning along the path that leads from Hegel to Plato ${ }^{5}$, will we be able to overcome the central deficit of our tradition of thinking, the comprehension of being marked by the bias toward the One.

Whoever approaches the system project proposed by Cirne-Lima for the first time encounters the following question: why does the reduction of the complex network of categories exposed in Hegel's Logic to a simple triad —identity, difference and coherence- involve ${ }^{6}$ an appeal precisely to the categories of the Doctrine of Essence, ignoring categories central to the Doctrine of the Concept? As we know, the Science of Logic has its high point only in the Doctrine of the Concept, since only now is the broad process of self-thematization of thinking consummated, and the Concept reaches its plenitude as Idea. Why then should the actualization project of dialectical ontology have recourse to a moment of expression of the truth sought that is still intermediary and in this sense inferior, and ignore richer categories, above all the richest of them all, precisely

\footnotetext{
5 This movement of return to Plato was decisive for the Gadamerian Project to overcome the monologic logic of Hegel's Concept, in a theory of dialogue invigorated within the philosophical hermeneutics. See Almeida, 2002, p.174. See also Gadamer: "The literary form of dialogue reinserts language and concept into the originary movement of conversation. The word is thus protected from all dogmatic abuses" (Wahrheit und Methode, in: GW, v. 1, p. 374).

6 Cirne-Lima,1996, p. 157ss.
} 
because it brings with itself the articulation of all previous categories in the complete categorial system, namely, the Idea itself?

We can approach an answer to this question by highlighting the central role of two philosophical problems in Cirne-Lima's system project: a) the need to deal with the classical objection that dialectic thinking infringes the principle of non-contradiction; b) the urgency in overcoming the necessitarian tendency that pervades Hegel's system. Now, as to the first problem, let us recall that identity and difference are synthesized in the Logic, precisely in the category of contradiction ${ }^{7}$. How can contradiction, a characteristic of what is disruptive in thinking, be the positive mark of a synthetic category that should overcome the impasses contained in the unilaterality of the previous thesis and antithesis?

Cirne-Lima's answer is initially conservative: it is not a matter, in dialectic, of emphasizing the novelty of a supposed logic that is the rival of formal logic, which, precisely because it breaks with the central assumptions of the latter, allows a positive treatment of the phenomenon of contradiction, a position followed, for example, by an long line of interpreters who treat dialectic as a type of logic of antinomies ${ }^{8}$; on the contrary, at least initially, it is a matter of preserving the traditional comprehension of logic, and relocating dialectic within this framework.

From this context emerges the proposal of thinking about the game of opposites in dialectic as a relationship between contraries, and not contradictories ${ }^{9}$, and substituting the category of contradiction by coherence like the intended synthesis, achieving the three central principles of Cirne-Lima's system project, identity, difference and coherence. This conservative aspect of Cirne-Lima's proposal, in his attempt to render dialectic not only legible in the eyes of the analytic thinkers, but also free of accusations of infringing the minimal conditions of rationality of discourse, is certainly reinforced in the proposal to formalize dialectic presented in Beyond $\mathrm{Hegel}^{10}$, as well noted by $\mathrm{J}$. Cabrera $^{11}$.

But no less important is Cirne-Lima's thesis, which is indeed far from being conservative, that this affinity between the principle of coherence and the principle of non-contradiction could only be ensured by reconstructing the original meaning of the latter. One of the crucial differences between Analytic and Dialectic is the emphasis of the

\footnotetext{
7 WL, 6, p. 64. In the short version of Logic, in the Encyclopedia, foundation appears as the desired synthetic category (Enz, 8, § 121).

8 See Luft, 2001, p. 132ss and Oliveira, 2004, p. 137ss.

9 Cirne-Lima,1996, p. 107ss.

${ }^{10}$ Cirne-Lima, 2006.

${ }^{11}$ Cabrera, 2009, p. 54.
} 
former on a type of strong rationality that, far from only demanding that contradictions be overcome, would operate under the assumption of the elimination by principle of the possibility that contradictions might emerge. Analytic thinking aspires to operate in a pure sphere, immune to contradictions, expressing itself as a type of logic of understanding in Hegel's terminology. Dialectic, on the contrary, begins with the real or at least potential presence of contradictions, in thinking or in being: there the initial "Principle of non-contradiction is inverted and is a 'Principle of Existing Contradiction'; this contradiction, according to Hegel is the motor and the force that moves both thinking and being"12. At the center of dialectic is the intention to broaden the concept of rationality, considering its narrow reading by the analytic thinkers to be a sub-system within a broad concept of reason ${ }^{13}$, which would agree with Hegel's proposal, now critically reconstructed, of differentiating two moments of logic, understanding and reason.

In order to carry out this Project, Cirne-Lima appeals to a deontic reading of the principle of non-contradiction. Here we come to the second of the fundamental problems, in the view of Cirne-Lima: the importance of overcoming the necessitarian tendency of Hegel's thinking. The deontic re-elaboration of the principle of non-contradiction would allow responding to the objection of necessitarianism, replacing the category of absolute necessity by the category of oughtness as a synthesis of relative necessity and contingency in Hegel's dialectic of modalities ${ }^{14}$.

Now, both the change in reading the identity-difference-contradiction triad and the dialectical reconstruction of the principle of non-contradiction require a dialogue with the Doctrine of Essence and not with the Doctrine of the Concept, which provides an initial explanation for the fact that the latter is not taken into account. But, in my view, there is another decisive reason why Cirne-Lima "deviated" from the Doctrine of the Concept: the abandonment of the Hegelian doctrine of the syllogism, the high point of the Science of Logic, indicates that in order to constitute a new dialectical ontology it is enough to reread the identity-difference-contradiction triad as identity-difference-coherence because this innovative formulation of

\footnotetext{
${ }^{12}$ See Cirne-Lima,1993, p. 68.

${ }^{13}$ Let us recall that Aristotle also had distinguished between a narrow concept and a broad concept of reason, when differentiating the syllogistic argumentation from the dialectic argumentation, the latter in his Topics (see Rohden, 1997, p. 139; see also Bubner, 1990). Although this anticipated the contemporaneous differentiation between own spheres of scientificity, namely, the usual distinction between hard and soft science, this distinction did not have any impact on the hard core of Aristotelian ontology. In a way the challenge of developing an unbiased theory of universal reason is the equivalent to exploring the ontological consequences of taking that differentiation seriously.

${ }^{14} \mathrm{WL}, 6$, p. 202ss.
} 
dialectic implies the deflation of classic ontology. Since coherence, and coherence alone, is the target of the dialectic process, Hegel's pretension of an exhaustive knowledge of what is real conveyed by the syllogistic structure of the Concept is rejected, and with this the pretension to dialectically "deduce" the theory of what is real —or rather the theory of what in the real is identical to the determinations that emanate from the Concept- from the theory of the first principles. We see that the descending dialectic, thus reconstructed, completely abandons the attempt to deduce the regional ontologies from the general ontology, a project that is dear to tradition.

But what is coherence aimed at as an oughtness? What does Cirne-Lima consider coherence? Now the principle of coherence is and remains, in Cirne-Lima, only the positive version of the principle of noncontradiction $^{15}$. As it happens, the principle of non-contradiction has the clear function of preserving a very specific comprehension of being, understood as the one that exists in their full identity and determination, as rendered explicit by the Aristotelian definition: "It is, that the same attribute cannot at the same time belong and not belong to the same subject and in the same respect"16. Aristotle is conveying, amid his theory of being, a very specific version of the objective reason, a very specific concept of logos.

It can then be perceived that, precisely this specific concept of reason was not altered in Cirne-Lima's rereading, but only its effectiveness was attenuated or weakened by the appeal to the structure in oughtness. As what is demanded by reason, coherence, it is the restoration of full identity and determination that characterize the being as such, in CirneLima as in Hegel there remains a concept of reason that is hostage to what I call the bias toward the One, and also imprisoned by the same typical restrictions of the logic of understanding: the maximum realization of what is required by reason is that situation of complete "harmony", in which the characteristic notes of the One -identity, invariance and determination- predominate over those of the Many - difference, variation and underdetermination ${ }^{17}$-, even if this goal of plenification, this "ideal situation", is in principle infinitely projected forward, by the structure in oughtness of the principle of coherence.

${ }^{15}$ Cirne-Lima,1993, p. 103.

${ }^{16}$ Met 1005b 15-20 (Transl. by W. D. Ross).

${ }^{17}$ Luft, 2014a, p. 959ss. 
Now I ask: how can the dialectic reason be freed from this bias toward the One, or from this bias toward the order, which appears inherent to it? How could the difference be, more than a subprinciple subordinated to the "highest law" of coherence (seen only as the highest form of identity ${ }^{18}$ ), one of the facets that constitutes coherence itself? How can one understand as coherence something more than the mere positive version of non-contradiction? I believe that the answer to this question comes not from the dialogue with Aristotle that, as we saw, predominates in Cirne-Lima's comprehension of the concept of coherence, but from the dialogue with Plato, as I shall show below.

\section{Plato or Platonism}

Even with all the influence of the so-called Tübingen School, followed and taken further by the Milan School, in reading Plato's works ${ }^{19}$, we remain hostages to the classical interpretation that emphasizes a dualist reading of the theory of ideas as the core of Platonic ontology. I associate with this typical reading the philosophical position called Platonism, and I define it as the one that affirms the objective existence of entities or structures to which one can attribute, exclusively, the characteristic notes of the One, namely, identity, invariance and determination, entities or structures to which, therefore, if this attribution is true, one can in no way attribute the characteristic notes of the Many, difference, variation and underdetermination ${ }^{20}$. We call Platonism, for instance, the theoretical position that advocates, in philosophy of Mathematics, "the metaphysical view that there are abstract mathematical objects whose existence is independent of us and our language, thought, and practices" ${ }^{\prime 21}$. In a previous essay ${ }^{22}$, I suggested the possibility of finding, even in a consideration that is purely immanent to the Plato's dialogues, and thus without the need to appeal to the esoteric work, an internal movement of self-criticism in the philosophical thinking that conducts to a non-dualist version of the relation between the One and the Many, allowing the dissociation of the late philosophy of Plato from "Platonism" as defined above. I now want to explore this rereading of Plato, with the explicit intention of seeking an unbiased understanding of logos or objective reason in dialectic. I am convinced that this innovative understanding was at least suggested by Plato himself, as we shall now see.

\footnotetext{
${ }^{18}$ Cirne-Lima, 2006, p. 158ss.

${ }^{19}$ Lima Vaz, 1990.

20 This terminology will be further clarified later.

${ }^{21}$ Linnebo, 2013.

22 E. Luft, 1996.
} 
Plato's work can be in large measure considered as an extensive meditation on the problem of not-being: in more urgent and decisive way than the original question of being as presented by Parmenides, it is the doubt introduced by the Sophists that really creates an enigma. The best way of becoming exposed to this enigma is to take very, very seriously, despite the ironic hues of the testimony bequeathed by Sextus Empiricus, the theses raised by Gorgias: "nothing is (ouden estin)" secondly, that even if anything is, it is inapprehensible (akatalêpton) to human beings; thirdly, that even if anything is apprehensible, yet of a surety it is inexpressible and incommunicable to one's neighbour"23.

The statement "ouden estin" is not rarely translated as "nothing exists ${ }^{124}$, which detracts from the original meaning, transforming it into an obvious nonsense, since denying existence in general is directly contradictory to the act of speech in which this denial is expressed, itself already assumed to exist. Let us recall, here, that ontology should not be understood, when we refer to the preponderant vision of the Greek theory of being, as the theory of existence, but rather as the theory of what exists permeated by logos, by objective reason. It is a very specific version of this logos that is at issue here. The first Gorgian sentence is against the concept of "being" (to on) in its proper and profound meaning, denying the basic assumption that the notes defining the One -identity, invariance and determination - could be applied to what exists. To exist as Pyrrhos will later state, is simply to appear. The patterns that we find in the real, if they exist, are like mutant, unstable shapes that we find in the clouds that, hardly have they appeared, already fade. Pyrrhos' aims at the same that Gorgias did: the "denial of the being" ${ }^{125}$, and the corresponding (hypothetical) affirmation of the pure Many.

As we can elicit from the testimony of Sextus Empiricus, the skeptical doctrine of Gorgias, a decisive mark of major lines of the coming skepticism, is a theory of dispersion or unrestricted multiplication. Appearing is a type of dispersed existence, which is not unified by any unvarying law or pattern. The first sentence of Gorgias denies being, at the same time as it affirms the radical dispersion of phenomena; on the other hand, the second sentence, the statement of the unfeasibility of apprehending what exists by some epistemic agent, is anchored in the radical dispersion of the cognitive faculties: "And just as the things

\footnotetext{
${ }^{23}$ I follow closely, here and in the citations below, the English version by R.G.Bury (in: Sextus Empiricus, 1997, v.I, 65ss), with occasional adjustments if necessary.

${ }^{24}$ Which is the case in the Bury's translation.

${ }^{25}$ Reale, 1994, v. III, p. 403.
} 
seen are called visible because of the fact that they are seen, and the audible termed audible because of the fact they are heard, and we do not reject the visible things because they are not heard, nor dismiss the audible things because they are not seen (for each object ought to be judged by its own special sense and not by another), - so also the things thought will exist, even if they should not be viewed by the sight nor heard by the hearing, because they are perceived by their own criterion"26. For instance, we sink a branch into the water, and it looks crooked to us, but our sense of touch tells us that it is straight, and abstract thinking - the use of the conceptual tools of physics - confirms this, but, according to the corrosive hypothesis of skepticism, what we have is really the dispersion of faculties, each one operating in its way and not unified by any operation or higher order faculty.

Finally, Gorgias' last sentence states that even if there is a being, and being able to apprehend, this knowledge cannot be communicated to the others, since the concepts that we use for this purpose suffer from what we could today call radical semantic dispersion, being interpreted diversely by different epistemic agents. Gorgias' skepticism is broad, involving an ontological skepticism, a cognitive skepticism and a linguistic skepticism, and each of these moments of integral skepticism carries with it the same basic hypothesis, the assumption that the Many, with its dissipative force, and not the One holds in everything there is. The old skepticism hypothetically opposes to the theory of the One a metaphysics of the not-being, a kind of antiontology or radical acosmism ${ }^{27}$.

\section{Parmenides}

The first Platonic response to this enigma of not-being is not the pure and simple denial of appearing, since this would imply the return to Parmenides' position, or at least the statement of a kind of panlogism: if all is pure being and pure logos, the emergence of false thoughts would initially be impossible, as will later be emphasized by the Sophist dialogue: no, Plato will not deny the presence of appearing, but will emphasize the equal presence of an eidos, a form that underlies it. This duplication of the world, deployed between the sensible and intelligible realms, the first referring to aisthêton, and the second to noêton, is the mark of Platonism, of the theory of ideas, in its possibly classical version, finding its high point in the famous Book VII of the Republic, and its

\footnotetext{
26 Sextus Empiricus, 1997, v. I, 81.

${ }^{27}$ For a similar contemporary approach, see Conche, 1990.
} 
intuitive expression in the allegory of the cave. The sensible realm is permeated by a dissipative and disaggregating "logic", an irreparable tendency to losing itself in the infinite, only contained by the integrating force of the idea. The sensible realm takes on the dissipative function, formerly carried out by the not-being in Gorgias, while the intelligible realm, the only being in the full sense of the word, takes on the unifying function, rendered feasible by the methexis or participation of the sensible in the intelligible.

It happens that, brought to its logical conclusion, this dualist version would lead to the affirmation of the full ontological independence of both poles of the opposition, leading into the reciprocal enigma of a One without a Many, and vice-versa, and rendering the very doctrine of participation unfeasible. This is what will become explicit in the overwhelming criticism to this reading that we find in the Parmenides dialogue. This criticism ironically is conveyed by the homonymous character of a young, immature Socrates who appears as the defender of the theory of ideas in its dualist version. Among the various objections I would like to highlight two that appear decisive. The first is the famous objection of the "third man", as it will later be called by Aristotle ${ }^{28}$. If the idea takes care of the unity of sensible multiplicity, what ensures the unity of this new multiplicity that was introduced now, not concerning the plurality of the sensible, but the counterpoint itself between sensible and intelligible? Would we need a new idea here? That is, besides the idea of man that takes care of the unit underlying the many men who appear in the sensible realm, would we now need a third one, neither ideal, nor a phenomenon, that would ensure the unity of the idea of man and his phenomenic counterpart? But, needing a "third man", would we not need a fourth and a fifth?

The second critique concerns the deficit inherent to the way of proceeding itself, in which the theory of ideas is rooted, a procedure that we might describe as typological. Let us assume that ideas exist for noble things, such as human beings, justice, beauty, etc. but there will likewise be ideas for insignificant things, such as "hair" or "mud"29? If to each group of phenomena we attribute a corresponding form, and there are potentially infinite groups of phenomena to be discovered in the sensible realm, would there also be infinite forms? If that were so, the ontology of ideas would be in trouble, since the tendency to become lost in the infinite of the sensible realm would be transferred to the intelligible realm, which would completely lose its unifying function.

\footnotetext{
${ }^{28}$ Met., 990b 17; 107913.

${ }^{29}$ Parmenides, in: SW, v. VII, 130c.
} 
From the epistemological standpoint, on the other hand, the advocate of the theory of ideas, far from being able to explain the sensible world by appealing to direct knowledge of ideas, would always be trailing behind the new discoveries made, every moment, by those who describe the phenomena and always revealing new patterns to be "explained"; ideas would be a posteriori conceptual duplications of the phenomena, and the knowledge of the intelligible would be, deep down, a purely misleading artifice.

How can one situate these trenchant critiques of the theory of ideas in Parmenides, in the general body of Plato's work? Could the theory of ideas actually be the work of Socrates (Burnet, Taylor) ${ }^{30}$ ? Do the critiques point to the presence of distinct phases in the further improvement of Plato's theory of ideas (D. Ross)? Could the dialogue be bringing to the fore enigmas that could only be overcome in the late work of Plato, which anyhow could only be explained by appealing to the unwritten doctrine (Tübingen/Milan School), or does it contain only a kind of "logical exercise" for propedeutic purposes to understand the truth (Grote, Robinson) ${ }^{31}$ ? Here it is not possible to take a position regarding this complex issue, but I would like to suggest an hypothesis, possibly to be developed in future work, in that Plato might actually be reviewing the dualist reading that comes through in Phaedo and in the Republic, and slowly going towards an increasingly sophisticated and non-dualist version of his ontology. I also believe that this self-critical development can be found in the exoteric work of Plato itself, namely, in the written dialogues, even if we can reinforce the understanding of what would be his late ontology, with an appeal to the (esoteric) unwritten work.

I think this way not only because the dialogue Parmenides is sufficiently explicit in the criticism of the dualist reading of the theory of ideas, but because Plato's later work ${ }^{32}$ is sufficiently innovative to reveal that there is something new in the late dialogues. What is this new? A gradual integration of the Many to the sphere of the first principles. As I said before, all of Plato's work can be seen as an extensive meditation about the problem of not-being. The distinction between intelligible and sensible, (especially in the Republic) already gives the Gorgian not-being an ontological status, accepting, as opposed to the theory of Parmenides, that the Many have their own ontological locus. However, with the impasse of the dualist reading that, on supposing the excluding

\footnotetext{
${ }^{30}$ See Ross, 1951, p. 157.

${ }^{31}$ Ross, 1951, p. 99-100.

32 There is a consensus among the interpreters, that the Republic dialogue is earlier than Parmenides, and that the Sophist is later than Parmenides and earlier than Philebus (see. Ross, 1951, p. 2).
} 
opposition between the One and the Many, ultimately makes the theory of participation unfeasible (as shown by Parmenides), the not-being ultimately is reconsidered and gains an entirely new ontological status, and is elevated to a moment in the theory itself of the great kinds in the Sophist dialogue. Finally, as we shall see, Philebus marks the rise of a daring ontological theory in which the One and the Many appear as the great kinds and the fundamental causes of all that exists.

\section{$* * *$}

\section{Sophist}

In the beginning, the Sophist presents as great kinds the pairs rest (stasis) and motion (kinêsis), accompanied by being. It should be noted that in the dualist version, motion would be an appropriate category to describe the sensible, but now the category appears in symmetrical opposition to its pair, rest. Here Plato reverberates a theory that is already present in Phaedrus, the thesis that motion does not characterize only the dissipative tendency of the phenomena, seating Cratylus' skepticism in the homonymous dialogue, nor only a motion for what is motionless and identical to itself, as presented in $\mathrm{Phaedo}^{33}$, but equally the unifying force of the active self-relationship of the soul, conceived as an eternal selfmover ("to hauto kinoun ${ }^{34 ")}$. Now Plato will bring to the light the central trait of all of ontology that considers itself dialectic, its relational character: the great kinds are not merely there, containing their determinations in isolation, but they are bonded by relations of determination and distinguished from each other by the way this relation occurs. Rest and motion are conceived by Plato as enantiôtata ${ }^{35}$, opposites that exclude each other and only participate mutually through the mediation of a third, the being. Rest is not motion and motion is not rest, but both are. What do we want to say when we state that something is? As we saw previously, being does not indicate only existence, but an existence permeated by logos, and the central trait of this logos is full identity and determination. Rest and motion, as they hold the primary trait of self-identity, participate in being, but as they are different among themselves, they participate in the not-being, and here Plato finds the answer to the central question of the Sophist: not-being is only the difference and the false thought is simply the confusion of kinds ${ }^{36}$.

\footnotetext{
${ }^{33}$ Phaedo, in: SW, v. IV, 79d.

${ }^{34}$ Phaedrus, in: SW, v. VI, 245c.

${ }^{35}$ Sophist, in: SW, v. VII, 250a.

${ }^{36}$ Here emerges the first version of what will later be formulated by Aristotle as the principle of non-contradiction.
} 
But there is a crucial difference between the rest /motion and identity (being (on))/difference (not-being (mê on)) pairs. While rest and motion only participate among themselves indirectly through the mediation of being, identity and difference participate among themselves directly. Now we have the four kinds, rest/movement and identity(being)/difference (not being), but Plato will soon explain that one must not make the mistake of purely and simply identifying being and identity, since 'being' can be said, sometimes about the beings who are "themselves by themselves" (auta kath' hauta), at other times about those who are only "in relation to other things" (pros alla) ${ }^{37}$. Treated in its relative sense, being is only the other of the difference, namely identity; considered in its absolute sense, being can and should be treated as the full autonomous self-reference, the full self-identity of the One itself.

Here we have not only a relational ontology, but an elaborate conceptualization of the hierarchical structure among kinds, since rest and motion are clearly below identity and difference, due to the force of their mutual relationship, since they depend on the presence of a third, the being, to ensure their bonding. On the other hand, identity/difference are inferior to the One, or to the absolute being, because they depend on each other to ensure their mutual determination, as opposed to the One that does it through the pure relationship with itself. If we were to follow this line of reasoning, maybe we could reconstruct Plato's entire ontology as a continuous grading of entities established by the difference between degrees of determination or by the force of their bonding, and we would come very close both to the metaphysics of Plotinus - that descends from the One to intellect, from this to the world soul (and individual souls), and from this to matter-, and to the late metaphysics of Plato schematized by $\operatorname{Vogel}^{38}$, and followed not without restrictions, as we shall see, by Gaiser ${ }^{39}$, presenting the One as the first principle, followed by the ideas, by the mathematical objects and by the sensible, with the Many (apeiron) at the base of the pyramid.

\section{Philebus}

Although this systematization that privileges the One as a principle may befit the difference between absolute and relative being presented in the Sophist, as we showed above, it is not so with the radical novelty

\footnotetext{
37 Sophist, in: SW, v. VII, 255c.

${ }^{38}$ See Vogel, 1953.

39 Gaiser, 1998, p.21.
} 
introduced by Philebus, which elevates the One and the Many, peras and apeiron, to co-originary and mutually determined principles, namely to correlative opposites that would reside in the heart of Platonic metaphysics. This is the main thesis that I want to advocate here: the slow rise of the Many in the ontological hierarchy, which we see in this true work in Becoming, forged by Plato's dialogues, to say about Plato what Tilliette said of Schelling, finds its high point in Philebus.

Like many of Plato's dialogues, Philebus has a simple and everyday theme, pleasure, which soon is transformed into the symbol of a complex, rich metaphysical theory. Let me use an even more ordinary image, by one who has so often taken his children to contemporaneous birthday parties, real banquets for the parents... Imagine yourself standing before a table full of sweet and savory party snacks of all kinds, a remarkable invitation to extravagant eating. The blind impulse that will soon emerge to satisfy desire, and will result in a day of excesses, lies at the core itself of the logic of pleasure, structured by the tendency to lose oneself in the infinite or the unlimited (apeiron). After a night's suffering from the regrettable consequences of this small loss of control, you will make a plan for the next time: "I'll eat only 6 sweet and 6 savory snacks, and nothing else." You will be setting a limit (peras) on the unlimited and avoiding the disastrous consequence of going deeper into the logic of pleasure and possibly sinking, not from a passing feeling of sickness but, at its extreme, of a pure and simple collapse of the body. In its self-organizing activity, as we would say today, our body is not guided by a movement of potentiation of the One, of the limit and suppression of the Many, of the unlimited, but by an adequate balance between both, for an adequate measure which is the immanent target of this game of the One and the Many forged by the nous or Intelligence, not only the abstract intelligence of thinking, which, consciously, limits the will, but the spontaneous intelligence of our own body in its movement of self-organization, and finally of the entire universe, as ruled by a universal nous ${ }^{40}$.

These arguments are, in my opinion, sufficient to show that the strict dualism between the One (ideas) and the Many (sensible objects) that occurs in Platonism, already challenged in Parmenides and in the Sophist, collapses completely from Philebus onwards. In this sense, it is not possible to speak, as Gaiser wishes, of an "insuperable dualism"41 of principles, since dualism is only applied to radically independent ontological spheres or entities. We can talk about dualism between intelligible and sensible, in the case of Platonism, or between res extensa

\footnotetext{
${ }^{40}$ Philebus, in: SW, v. VIII, 30ac.

41 Gaiser, 1998, p. 10.
} 
and res cogitans in Descartes, or between thing-in-itself and phenomenon in Kant, but one can in no way speak of dualism, when what is at stake is precisely the contrary, the nonindependence of the One and the Many, that is their correlative opposition. There is no One without Many, nor vice-versa.

Even so, we may counter this argument, Plato is not proposing a symmetrical relationship between the One and the Many. Possibly, even emphasizing the correlative character of the One and the Many in Philebus, Plato still had in mind that the universal nous aims at the measure or the order that are given precisely by the predominance of the One over the Many. We might reconstruct the entire hierarchical structure of Plato's ontology by establishing degrees of determination of what exists, the maximum expression of determination being the type of strict bonding that we find between the One and the Many, as the main correlative principles, followed by the slightly less strict bonding that we observe among ideas, a lower potency expression of the very regulating force of the One-Many, then leading into the mathematical objects, into the phenomena and pure disfigured matter representing the same dialectic of the One and the Many, but with the maximum predominance of the latter over the former. In this way we would be very close to the reconstruction of the late philosophy of Plato proposed by Gaiser ${ }^{42}$.

Possibly this was, in fact, the answer given by Plato to the enigma of the Many in his late philosophy. In this case Plato's philosophy would continue to be marked by the bias toward the One, even taking into account the correlative character of the One-Many opposition, since only the maximum predominance of the One over the Many would represent the maximum expression of the logos. However it should be asked what would happen if we continued the path blazed by Plato, emphasizing not only the correlative character of the One and the Many, but an unbiased approach to logos or objective reason.

\section{Without bias}

Previously we saw that Plato's work can be understood as a long meditation about the problem of not-being, and that not-being expresses the dissipative, and if not contained or limited, the disruptive tendency of the Many. We then have two categories at the core of Greek metaphysics: the One expressing determination or, in its entire abstraction (if possible) from the Many, the absolute or complete determination of the entirely self-contained being; the Multiple expressing the (in)determination or

${ }^{42}$ Gaiser, 1998, p. 97. 
denial of determination or in its entire abstraction (if possible) from the One, the pure and simple indetermination. These two abstractions, of the One toward the Many, and vice-versa, imply Platonism.

Now, it is precisely this abstraction that the decisive sentence of Philebus is denying: "And the people of old, superior to us and living in closer proximity to the gods, have bequeathed us this tale, that whatever is said to be consists of one and many, having in its nature limit and unlimitedness ${ }^{43}$ (peras de kai apeirian) ${ }^{144}$. There may be the maximum predominance of the One over the Many, or vice-versa, but there cannot be the One without the Many, or vice-versa.

The strangeness of this strictly dialectical reading of the first principles presented by the late Plato left its marks in Aristotle: "Those who treat the unequal as one thing, and the dyad as an indefinite compound of great and small, say what is very far from being probable or possible. For (a) these are modifications and accidents, rather than substrata, of numbers and magnitudes - the many and few of number, and the great and small of magnitude - like even and odd, smooth and rough, straight and curved. Again, (b) apart from this mistake, the great and the small, and so on, must be relative to something; but what is relative is least of all things a kind of entity or substance, and is posterior to quality and quantity"45. But this is precisely the thesis of the late Plato. The elevation of the Many to a correlative category of the One, implies: a) the adoption of a strictly relational ontology, since not only rest (and motion) or identity (and difference), but the One itself is determined by its correlative opposition to its pair; (b) the introduction of the "accident" in the core itself of the "substance", that is, since the One and the Many are strictly correlative, there cannot be anywhere the pure determination without underdetermination ${ }^{46}$, nor underdetermination without determination, but only a difference in degree of determination, associated with the predominance of the One over the Many, or vice-versa. Now this thesis implies the collapse of the dualism between sensible and intelligible. We could talk at most of a rich hierarchical ontology in which ontological

${ }^{43}$ I wish to highlight the fact that Schleiermacher translated peras and apeiron respectively as determination (Bestimmung) and indetermination (Unbestimmtheit) (see SW, v. VIII, 16c), instead of the usual limit and unlimitedness. Schleiermacher' choice is rich in meaning (see note 48 below).

${ }^{44}$ Philebus, in: SW, v. VIII, 16c. See Frede's translation: Plato, Complete Works (1997).

${ }^{45}$ Met 1088a 15-20 (Trans. by W. D. Ross).

${ }^{46}$ Here I strictly distinguish between "underdetermination" and "indetermination": underdetermination is the property of an event whose occurrence is only one among ' $n$ ' possibilities in a limited field of possibilities of occurrence; indetermination is the property of an event whose occurrence is only one among ' $n$ ' possibilities in an unlimited (unrestricted) field of possibilities of occurrence. Now, an unrestricted field of possibilities is no field at all. 
levels follow each other from the less determined to the most determined, or vice-versa. As previously mentioned, we do not know whether in fact Plato extracted all the consequences of this radical thesis, but we should do this all the same.

Now we come to the denouement, returning to the beginning. Dialectical ontology is a relational ontology: "only what is 'in relation to' remains determinate", or what comes to the same, "only what is coherent remains determinate". This is the very universal law inherent to all there is or can be, the objective reason that pervades every being. But what do we understand by "coherence"? Should we understand the principle of coherence, the universal law of dialectical ontology, just as the positive version of the principle of non-contradiction ${ }^{47}$ ? As we have seen, the principle of non-contradiction has the function of preserving a biased comprehension of being, understood as pure identity. Now, however, we encounter the radical thesis of the late Plato in Philebus, which, on affirming the strictly dialectic or correlative character of the One/Many pair, denies the One thought of as abstracted from the Many, and makes the traditional concept of substance collapse ${ }^{48}$. However, maybe even in the late Plato, the bias toward the One remains, and with this the assumption that measure and the reason only occur in the predominance of the One and its characteristic notes -identity, invariance and determination - over the Many and its notes — difference, variation and underdetermination-. Abandoning this bias takes to the ultimate consequences the movement of elevation of the Many to the sphere of the first principles, namely, the process of self-criticism conducted by Plato himself, as well as the deflationary movement resulting from the introduction of contingency into the heart of dialectical reason via an immanent critique of Hegel's system ${ }^{49}$. In this phase of our path in a descending dialectic, its branches, namely the one that follows Plato's influence on German idealism and comprises the immanent critique of Hegel's philosophy, and the other that accompanies and radicalizes Plato's self-criticism process, converge in a same deflationary relational ontology, or simply a network ontology.

\footnotetext{
47 See section one above.

${ }^{48}$ It is known that the whole Doctrine of Essence in Hegel's Logic also aims at the dissolution of the classical concept of substance (WL, v. 6). See also Theunissen, 1994.

${ }^{49}$ Luft, 2015, p. 56.
} 


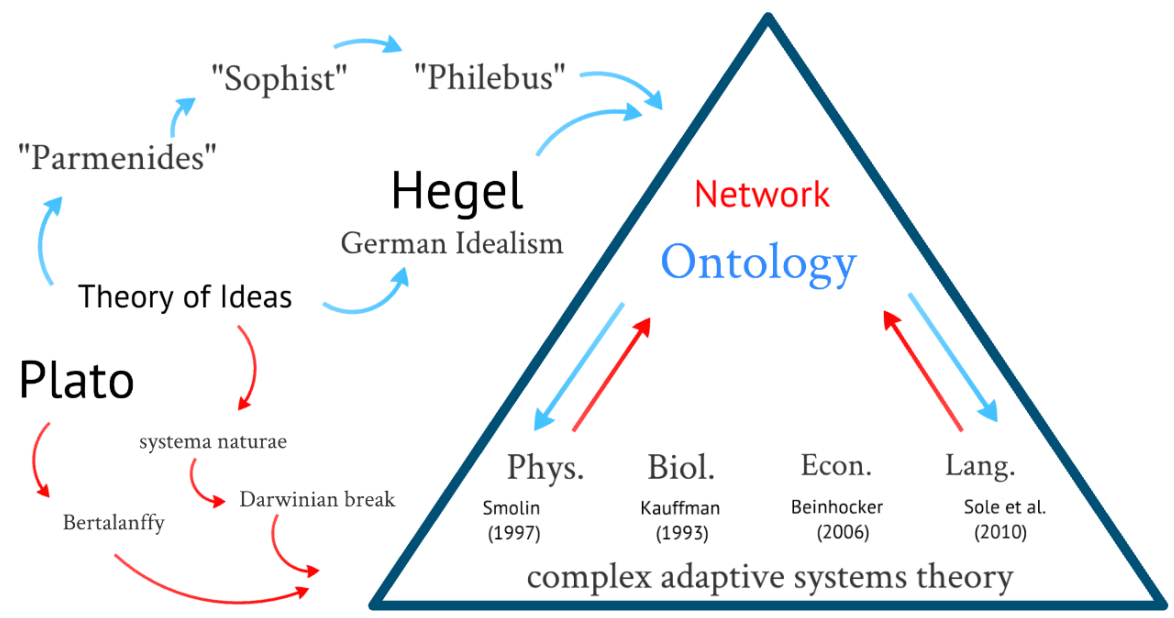

Descending dialectic: potential of immanence of philosophy

Ascending dialectic: potential of self-transcendence of the particular sciences

What do I consider here to be network ontology? "Only what is coherent remains determinate". Existing is not precisely being, but being in the tense process of determination which aims at coherence, and when it does not achieve it falls apart or becomes lost in incoherence. Coherence is the immanent target, the attractor of the entire process of determination, but there are many, potentially infinite ways of carrying it out between the extremes of the maximum predominance of the One over the Many, or vice-versa. While it occurs in the extreme face of the maximum predominance of the One over the Many, coherence is manifested as order, while when it occurs at the opposite face of the extreme predominance of the Many over the One, coherence is expressed as chaos.

Now let us perform an unusual thought experiment. Just imagine, Dear Reader, that you are located at an equal distance from the extremes of the maximum predominance of the One over the Many, and vice-versa, that is, in the company of that particular web of events that I call Leibniz's Configuration (in the figure below, the point at the extreme lower part of the circumference (L)), and embarking on a trip in the direction of maximum order (if we look directly at the same figure, the movement that goes to the left beginning at the Leibniz's Configuration), while a fellow adventurer follows the exactly opposite direction, aiming not at maximum order but at maximum chaos. During the course of the trip, you would be approaching the Parmenides' Configuration (P), while your colleague, to 
his own despair —or not? - would be closer and closer to the Gorgias' Configuration $(G)$. Where would this trip end? Apparently nowhere, or rather at a greater and greater distance between the two travelers. But this is not what in fact would occur. Let us come really close to the Gorgias' Configuration and assess where this movement of approach would take us. Now, Gorgias' Configuration, while it manifests itself as the maximum predominance of the Many over the One, does not have any stable determination except its own self-reference as a configuration, that is, at its extreme it reverts to the almost pure identity of the Parmenides' Configuration. On the other hand, the configuration which manifests itself at the opposite extreme, the Parmenides' Configuration is apparently very stable in its pure self-reference, but, in fact, precisely in its almost full invariance, it is the most open to potential collapses and, therefore, the most unstable, because it is incompatible with any other of the infinite possible reconfigurations enabled by the universal law of coherence itself; in its extreme face, Parmenides' Configuration reverts to the Gorgias' Configuration. Both the opposite manifestations of coherence revert, at their extremes, one into the other and, in their continuous oscillation, coincide. Following their antagonistic travels, aiming at the extreme opposites of order and chaos, you and your friend would end up by meeting again in the Cusanus' Configuration (C) (at the upper point of the circumference). In this brief thought experiment, we delimited the map of the dynamic logical space, the field of all possible thoughts and all possible forms of existence.

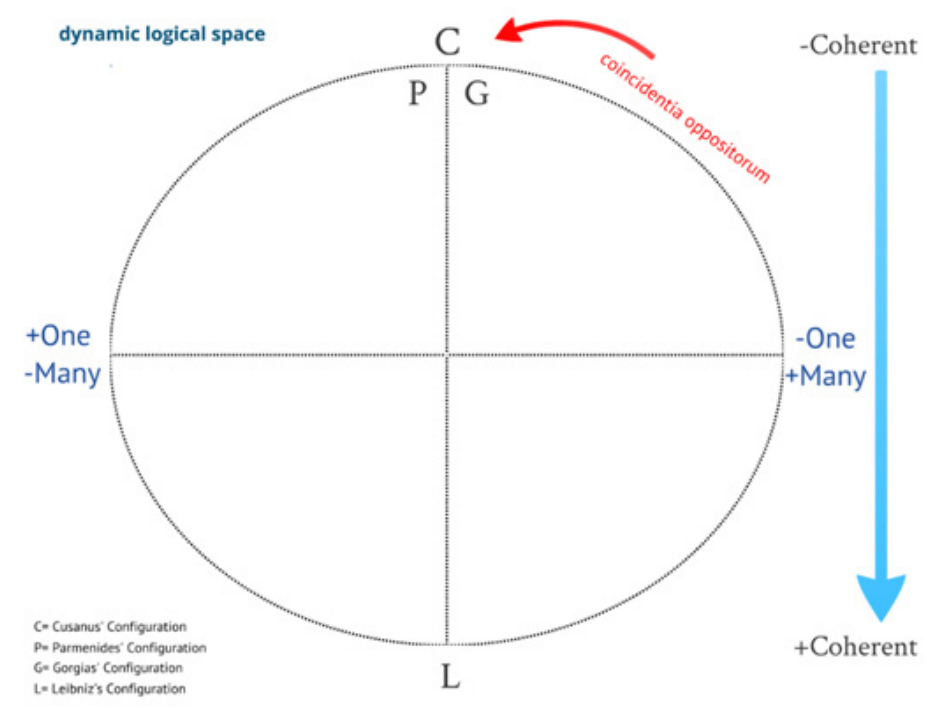


Following our path in descending dialectic, we can articulate this strictly speculative theory with one of the lines that are in the foreground of contemporary science, network science. Thus we will not be deducing the regional ontologies from the general ontology, but articulating them and evaluating their mutual compatibility. We cannot prove the truth of general ontology based on the regional ontologies, but we can refute it with robust empirical counterproof or accurate counterarguments. All that happens and can happen occurs in or as a configuration. Configurations inserted in time or concrete configurations we call networks, configurations abstracted from time we call graphs (the privileged field of research of mathematics $)^{50}$. Although the dialectical ontology does not begin with any bias, neither a bias toward order, nor a bias toward chaos, leaving the field of possibilities entirely open, the dynamic evolutionary environment itself, which sprouts from this deflationary ontology, makes a bias emerge toward the lower quadrants of the circumference (see the arrow pointing downwards, on the right side of the circumference, in the figure above) toward those concrete configurations that the network theoreticians call scale-free networks, as opposed to regular networks (which present themselves near the Parmenides' Configuration) and random networks (which manifest themselves in the proximity of the Gorgias' Configuration). It is not difficult to understand why evolution makes this bias emerge: random networks are too unstable to preserve any configuration pattern in time, which will thus last; regular networks, in turn, have the advantage of stability, but the disadvantage of non-adaptation to an environment that is continually changing. On the contrary, scale-free networks have the advantage of sufficient stability to last, and sufficient flexibility to adapt.

(Authorized translation by Hedy Lorraine Hoffman)

\section{References}

ALMEIDA, Custódio Luís Silva de. Hermenêutica e Dialética: dos Estudos Platônicos ao Encontro com Hegel. Porto Alegre: Edipucrs, 2002.

Aristotle. Metaphysics [Met]. Trans. by W. D. Ross. In: The Internet Classics Archive. <http://classics.mit.edu/Aristotle/metaphysics.html>. Accessed 15 May 2017.

BARABÁSI, A.-L. Network Science. Network Science Book. 2012. < http://barabasi. com/networksciencebook>. Accessed 15 May 2017.

BEINHOCKER, Eric. Origins of Wealth: Evolution, Complexity and the Radical Reshaping of Economics. Boston: Harvard Business School Press, 2006.

50 See Barabási, 2012. 
BUBNER, Rüdiger. Dialektik als Topik: Bausteine zu einer lebensweltlichen Theorie der Rationalität. Frankfurt am Main: Suhrkamp, 1990.

CABRERA, Julio. "Lógica y dialéctica: lecturas oblicuas". In: Cirne. Sistema e objeções. Edited by Adriano Naves de Brito. São Leopoldo: Editora Unisinos, 2009. p. 39-71.

CIRNE-LIMA, Carlos. Beyond Hegel. A Critical Reconstruction of the Neoplatonic System. 2006. <http://carloscirnelima.org > . Accessed 15 May 2017.

. Dialética para principiantes. Porto Alegre: Edipucrs, 1996.

. Sobre a contradição. Porto Alegre: Edipucrs, 1993.

CONCHE, M. Orientation philosophique. Paris: Presses Universitaires de France, 1990.

DOSTAL, Robert J. "Time and Phenomenology in Husserl and Heidegger". In: The Cambridge Companion to Heidegger. Edited by Charles B. Guignon. Cambridge: Cambridge University Press, 1993. p. 141-169.

GADAMER, Hans-Georg. Gesammelte Werke [GW]. Tübingen: Mohr, 1990.

GAISER, Konrad. Platons ungeschriebene Lehre. Studien zur systematischen und geschichtlichen Begründung der Wissenschaften in der Platonischen Schule. 3. ed. Stuttgart: Klett-Cotta, 1998.

HEGEL, Georg Wilhelm Friedrich. "Wissenschaft der Logik [WL]". In: Werke in 20 Bänden. Edited by Eva Moldenhauer and Karl M Michel. 2. ed. Vol. 5, 6. Frankfurt am Main: Suhrkamp, 1990.

"Enzyklopädie Der Philosophischen Wissenschaften [Enz]." In: Werke in 20 Bänden. Edited by Eva Moldenhauer and Karl Markus Michel. Vol. 8, 9, 10. Frankfurt am Main: Suhrkamp, 1989.

KAUFFMAN, Stuart A. The Origins of Order. Self-Organization and Selection in Evolution. Vol. 26. 6. New York: Oxford University Press, 1993.

LIMA VAZ, Henrique C. de. "Um Novo Platão?" Síntese Nova Fase, 50 (1990), p. 101-113.

LINNEBO, Øystein. "Platonism in the Philosophy of Mathematics". The Stanford Encyclopedia of Philosophy. Winter 2013. < https://plato.stanford.edu/ entries/ platonism-mathematics > . Accessed 15 May 2017.

LUFT, Eduardo. "Hegel's Science of Logic as Metalogic". Kritisches Journal 2.0, 1 (2015), p. 44-59.

. "Dialectic and Network Ontology. The Concept of Reason after Hegel". In: Los Aportes del Itinerario Intelectual de Kant a Hegel. Edited by Héctor Ferreiro, Thomas Sören Hoffmann, and Agemir Bavaresco. Porto Alegre: Edipucrs/Editora Fi, 2014a. p. 946-978.

. "Platão ou Platonismo: um tópico em dialética descendente". In: Hermenêutica e dialética: entre Gadamer e Platão. Edited by Luiz Rohden. São Paulo: Loyola, 2014b. p. 65-90.

. As sementes da dúvida. Investigação crítica dos fundamentos da Filosofia Hegeliana. São Paulo: Mandarim, 2001.

. "Contradição e dialética". Síntese Nova Fase, 23, 75 (1996), p. 455-500.

LUFT, Eduardo; CIRNE-LIMA, Carlos. Ideia e Movimento. Rio de Janeiro: Civilização Brasileira, 2012. 
OLIVEIRA, M. A. de. Dialética hoje. Lógica, Metafísica e Historicidade. São Paulo: Loyola, 2004.

PLATO. Complete Works. Edited by John Madison Cooper. Translated by Dorothea Frede. Indianapolis/Cambridge: Hackett, 1997.

PLATON. Sämtliche Werke in Zehn Bänden [SW]. Edited by Karlheinz Hülser. Frankfurt am Main/Leipzig: Insel, 1991.

REALE, Giovanni. História da filosofia antiga. Translated by Henrique C. de Lima Vaz and Marcelo Perine. Vol. I-V. São Paulo: Loyola, 1994.

ROHDEN, Luiz. O poder da linguagem. A arte retórica de Aristóteles. Porto Alegre: Edipucrs, 1997.

ROSS, William David. Plato's Theory of Ideas. Oxford: Clarendon Press, 1951.

SEXTUS Empiricus. Against the Logicians. Translated by R. G. Bury. Vol. I, II (Loeb). Cambridge: Harvard University Press, 1997.

SMOLIN, Lee. 1997. The Life of the Cosmos. New York: Oxford University Press.

SOLÉ, R. V.; COROMINAS-MURTRA, B.; VALVERDE, S.; STEELS, L. "Language Networks: Their Structure, Function and Evolution". Complexity, 15, 6 (2010), p. 20-26.

THEUNISSEN, Michael. Sein und Schein. Die kritische Funktion der Hegelschen Logik. 2. ed. Frankfurt am Main: Suhrkamp, 1994.

VOGEL, C. J. de. "On the Neoplatonic Character of Platonism and the Platonic Character of Neoplatonism". Mind, 62 (1953), p. 43-64.

\section{Endereço postal:}

Programa de Pos-Gradução em Filosofia - PUCRS

Av. Ipiranga, 6681 - Prédio 5

Porto Alegre, RS, Brasil

Data de recebimento: 16-05-2017

Data de aceite: 08-09-2017 